\title{
Association between Carbohydrate, Vitamin C, Vitamin E, and HBA1C Level
}

\author{
Dwi Astuti Dian Andarwati'), Bhisma Murti²), Endang Sutisna Sulaeman²) \\ 1)Masters Program in Nutrition, Universitas Sebelas Maret \\ ${ }^{2)}$ Masters Program in Public Health, Universitas Sebelas Maret
}

\begin{abstract}
Background: Diabetes is now a disease that is a major concern both globally and regionally and is the leading cause of death in most countries. HbA1c levels are used to measure longterm glucose levels in patients with type 1 and 2 Diabetes Mellitus (DM). Restrictions on carbohydrate diets have the greatest effect on decreasing blood glucose levels. Nutritional interventions with the provision of vitamin $\mathrm{C}$ and vitamin $\mathrm{E}$ can reduce inflammation and oxidative stress as a strategy to prevent the occurrence of DM. The purpose of this study was to determine the relationship of carbohydrate intake, vitamin $\mathrm{C}$ and vitamin $\mathrm{E}$ with $\mathrm{HbA1c}$ levels. Subjects and Method: This was a cross sectional study conducted at Prodia Surakarta Clinic, Surakarta, Central Java, Indonesia. A sample of 150 study subjects was selected by fixed disease sampling. The dependent variable was HbA1c level. The independent variables were carbohydrate and vitame E. The data were collected by questionnaire and 24-hour food recall. The data were analyzed by a multiple logistic regression.

Results: High carbohydrate intake increased HbA1c level $(\mathrm{OR}=2.84 ; 95 \% \mathrm{CI}=0.72$ to 11.12; $\mathrm{p}=0.133)$, while high intake of vitamin E lowered $\mathrm{HbA1c}$ level $(\mathrm{OR}=0.12 ; 95 \% \mathrm{CI}=0.02$ to 0.64; $\mathrm{p}=0.012$ ).
\end{abstract}

Conclusion: High carbohydrate intake increases HbA1c level, while high intake of vitamin $\mathrm{E}$ decreases HbA1c level.

Keywords: diabetes, HbA1c, karbohidrat, vitamin C.Vitamin E

\section{Correspondence:}

Dwi Astuti Dian Andarwati. Masters Program in Nutrition, Universitas Sebelas Maret, Jl. Ir. Sutami 36A, Surakarta 57126, Central Java. Email: dianandarwati@yahoo.com. Mobile: 081329588344.

\section{BACKGROUND}

Diabetes is now a disease that is a major concern both globally and regionally and is the leading cause of death in most countries (Nanditha et al., 2016). The prevalence of prediabetes in Indonesia is very large (10\%) so prevention strategies need to be carried out both for prediabetes and the progression of prediabetes to diabetes (Soewondo and Pramono, 2011).

Detecting prediabetes is a fundamental strategy to maintain the transition to diabetes. After detecting prediabetes, a mangement plan must be implemented to prevent or slow the transition to diabetes. If there is no management to improve health, $15 \%-30 \%$ of prediabetes patients will become diabetic within 5 years. Physical activity and good nutritional regulation can prevent or slow down progression into diabetes (Bushman, 2015). Diets, especially vitamin $\mathrm{C}$, vitamin $\mathrm{E}$ and alcohol affect HbA1c (Boeing et al., 2000).

HbA1c is an important monitoring tool in the management of patients with diabetes mellitus (Paputungan et al., 2014). HbA1c levels were used to measure glucose levels in the long run in patients with 
diabetes mellitus (Diabetes Mellitus) type 1 and 2, and to determine the treatment response and risk of diabetes complications (Weykamp and $\mathrm{Ph}, 2013$ ). The lower the value of HbA1c is the better, this is because the lower HbA1c can prevent complications in diabetic patients (Hinzmann et al., 2012).

The development of DM can be reduced by a diet of antioxidants vitamin $\mathrm{C}$ and vitamin E (Montonen., 2004). In DM there is a change in oxidative status characterized by changes in endogenous antioxidant activity as well as increased oxidative biomolecular damage. Therefore, exogenous antioxidants are needed as inhibitors of oxidative damage in the body, in the form of vitamin C, vitamin E and glutathione (Setiawan and Suhartono., 2005). In prediabetes patients, vitamin $\mathrm{C}$ is greater than normal people (Wilson et al., 2017). Restrictions on carbohydrate diets have the greatest effect on decreasing blood glucose levels (Feinman et al., 2014). Nutritional intervention by providing micronutrients of vitamin $\mathrm{C}$, vitamin $\mathrm{D}$ and vitamin $\mathrm{E}$ can reduce inflammation and oxidative stress as a strategy to prevent the occurrence of DM. This can also be applied to prediabetes patients (Bailo et al., 2011). Based on this background, the purpose of this study was to determine the relationship of carbohydrate intake, vitamin $\mathrm{C}$ and vitamin $\mathrm{E}$ with HbA1c levels.

\section{SUBJECTS AND METHOD \\ 1. Study Design \\ The design of this study was a cross sectional study. It was conducted at the Prodia Clinic in Surakarta, Central Java, Indonesia.}

\section{Population and Sample}

The study population was patients who came to Prodia Clinic and conducted HbA1c examinations. The sample size in this study was 120 people. The sampling was done using "fixed disease sampling". The study sample was selected which met the inclusion criteria, namely patients domiciled in Surakarta and exclusion criteria, namely the sample consumption of supplements of vitamin $\mathrm{C}$ and vitamin $\mathrm{E}$.

\section{Study Variables}

The dependent variable was HbA1c level. The independent variables were vitamin $\mathrm{C}$, carbohydrate, vitamin $\mathrm{E}$, gender, age, and physical outcome.

\section{Operational Definition of Variables}

Carbohydrate intake was the total carbohydrate derived from food and beverages consumed, which is obtained from consumption surveys using the method of consuming food frequency then compared with total energy intake, added or reduced based on gender, age, activity, weight and metabolic stress. The measuring instrument used was the FFQ form and Food Recall 24 hours 2 times. Dichotomous data coded o for high and 1 for low.

Vitamin C intake was total vitamin C sourced from food and beverages consumed, which is obtained from consumption surveys using FFQ and then calculated the amount of intake per day. The data were measured by FFQ and food recall 24 hours 2 times. Dichotomous data coded o for low and 1 for high.

Vitamin $\mathrm{E}$ intake was total vitamin $\mathrm{E}$ sourced from food and beverages consumed, obtained from consumption surveys using food frequency consumption method. They are asked about the average frequency, and the number of food portions over the past 1 month. The measuring instrument uses the FFQ form and Food Recall 24 hours 2 times. Dichotomous data coded o for low and 1 for high.

The level of HBA1C was an assessment of plasma glucose levels on average for 120 days. The measuring instrument 
uses the BioRad D-10 with the NGSP standardized high performance liquid chromatography (HPLC) method. The scale was categorical, coded o for high and 1 for low.

Physical exercise was physical activity that is carried out routinely and structured. The data were measured by questionnaire. The scale was categorical, coded o for low and 1 for high.

Age was the age of the subject during the study, the continous data transformed into dichotomous, coded o for $>45$ years old and 1 for $<45$ years old.

\section{Data Analysis}

The data were analyzed by univariate analysis, bivariate analysis, and multivariate analysis using a multiple logistic regression.

\section{Ethical Clearance}

This study received ethical ethics from the Health Research Ethics Commission of the Faculty of Medicine, Universitas Sebelas Maret, number 179/UN27.6/KEPK/2018.

\begin{tabular}{l} 
RESULTS \\
\hline 1. Univariate analysis \\
The results of this study indicated that the \\
age of the study subjects was mostly over 45
\end{tabular}

Table 1. Sample characteristics

\begin{tabular}{|c|c|c|}
\hline Characteristics & $\mathbf{N}$ & $\%$ \\
\hline \multicolumn{3}{|l|}{ Gender } \\
\hline Female & 88 & 58.7 \\
\hline Male & 62 & 41.3 \\
\hline \multicolumn{3}{|l|}{ Age } \\
\hline More than 45 & 89 & 59.3 \\
\hline Less than 45 & 61 & 40.7 \\
\hline \multicolumn{3}{|l|}{ Educational Background } \\
\hline High (above SHS) & 99 & 66 \\
\hline Low (below SHS) & 51 & 34 \\
\hline \multicolumn{3}{|l|}{ Occupation } \\
\hline Employee & 125 & $83 \cdot 3$ \\
\hline Housewife & 25 & 16.7 \\
\hline \multicolumn{3}{|l|}{ Physical Exercise } \\
\hline High & 36 & 24 \\
\hline Low & 114 & 76 \\
\hline
\end{tabular}

years old (59.3\%). Then from gender, female subjects were $58.7 \%$. While the level of education, most of them were mostly senior high school (66\%). Then from the occupation, most of them are employees (83.3\%). Then from the level of physical exercise, most are categorized in the low level (76\%). It can be seen in Tabel 1 .

\section{Bivariate analysis}

Bivariate analysis was performed using the chi square test. The results of bivariate analysis showed in Table 2. Table 2 showed that physical exercise, vitamin $\mathrm{C}$ and vitamin $\mathrm{E}$ were associated with $\mathrm{HbA1c}$ levels. Tabe 2 showed that high vitamin $\mathrm{E}$ decreased HbA1c levels $(\mathrm{OR}=0.10 ; \mathrm{p}=$ o.015). Carbohydrate intake increased HbA1c levels and it was statistically significant $(\mathrm{OR}=3.38 ; \mathrm{p}=0.080)$. High physical exercise reduced HbA1c levels but it was statistically non-significant $(\mathrm{OR}=0.33 ; \mathrm{p}=$ 0.452).

Age increased HbA1c level but it was statistically non-significant $(\mathrm{OR}=1.65 ; \mathrm{p}=$ 0.741). Gender was not associated with HbA1c level $(\mathrm{OR}=1.06 ; \mathrm{p}=1,000)$. Vitamin $\mathrm{C}$ reduced HbA1c level but it was statistically significant $(\mathrm{OR}=0.80 ; \mathrm{p}=0.743)$. 
Table 2. The relationship between sex, age, physical exercise, carbohydrate, vitamin $C$ and vitamin $E$ with HbA1c levels

\begin{tabular}{|c|c|c|c|c|c|}
\hline \multirow{2}{*}{ Variable } & \multicolumn{2}{|c|}{ HbA1c } & \multirow{2}{*}{ OR } & \multirow{2}{*}{$95 \%$ CI } & \multirow[b]{2}{*}{$\mathbf{p}$} \\
\hline & Low & High & & & \\
\hline \multicolumn{6}{|l|}{ Gender } \\
\hline Female & 82 & 6 & 1.06 & $0.28-3.92$ & 1.000 \\
\hline Male & 58 & 4 & & & \\
\hline \multicolumn{6}{|l|}{ Age } \\
\hline$\geq 45$ years old & 82 & 7 & 1.65 & $0.41-6.65$ & 0.741 \\
\hline$<45$ years old & 58 & 3 & & & \\
\hline \multicolumn{6}{|l|}{ Physical exercise } \\
\hline High & 105 & 9 & 0.33 & $0.41-2.72$ & 0.452 \\
\hline Low & 35 & 1 & & & \\
\hline \multicolumn{6}{|l|}{ Carbohydrate } \\
\hline High & 43 & 6 & $3 \cdot 38$ & $0.90-12.60$ & 0.080 \\
\hline Low & 97 & 4 & & & \\
\hline \multicolumn{6}{|l|}{ Vitamin $\mathrm{C}$} \\
\hline High & 49 & 4 & 0.80 & $0.21-2.99$ & 0.743 \\
\hline Low & 91 & 6 & & & \\
\hline \multicolumn{6}{|l|}{ Vitamin $\mathbf{E}$} \\
\hline High & 6 & 3 & 0.10 & $0.02-0.50$ & 0.015 \\
\hline Low & 134 & 7 & & & \\
\hline
\end{tabular}

Table 3. The results of multiple logistic regression analysis on the relationship of carbohydrate intake, vitamin $E$, sex, and physical exercise with HbA1c levels

\begin{tabular}{lccc}
\hline \multicolumn{1}{c}{ Variable } & OR & 95\% CI & p \\
\hline High carbohydrates & 2.84 & 0.72 to 11.12 & 0.133 \\
High Vitamin E & 0.12 & 0.02 to 0.64 & 0.012 \\
N observation $=150$ & & & \\
Nagelkerke $\mathrm{R}^{2}=14.4 \%$ & & & \\
\hline
\end{tabular}

\section{Multivariate analysis}

Table 3 described the results of multiple logistic regression on the relationship of carbohydrate intake, vitamin $\mathrm{C}$, vitamin $\mathrm{E}$, gender, and physical exercise with HbA1c levels. From the table 3, it can be seen that high carbohydrate intake increased HbA1c level but it was statistically non-significant $(\mathrm{OR}=2.84 ; 95 \% \mathrm{CI}=0.72$ to $11.12 ; 0.133)$. High vitamin $\mathrm{E}$ intake decreased HbA1c level and it was statistically significant $(\mathrm{OR}=0.12 ; 95 \% \mathrm{CI}=0.02$ to $0.64 ; \mathrm{p}=$ o.012).

\section{DISCUSSION}

The subjects of this study were 95 people (63\%) normal HbA1c levels, 46 people (31\%) prediabetes, 9 people (6\%) people with diabetes. This shows that the awareness of people to check themselves was good, possibly because the majority are highly educated and live in cities. According to Ramadhan and Marissa, 2015 people with higher education would usually have a lot of knowledge about health and have an awareness of maintaining health and influencing physical activity to be carried out. Knowledge is needed by individuals to improve their ability to choose and decide on the right actions to control their disease (Prasetyani, 2017). The level of education is also one of the factors that determine a person's behavior, and fosters the right attitude (Idris et al., 2013). Thus increasing self-awareness in terms of health, changing lifestyles towards healthier ones (Rahma- 
wati et al., 2016). This study supports a study from Sevin et al., (2009) where lower education was significantly associated with higher $\mathrm{Hb} \mathrm{A} 1 \mathrm{C}$.

\section{The relationship between carbohy- drate intake and HbA1c}

The subjects of this study showed that the majority (62\%) consumed low carbohydrates and low HbA1c values. In this study, it was seen that high carbohydrate intake increased the risk of high HbA1c. This is similar to the research of Tay et al. (2015); Ebe et al., (2017) and Haimoto et al., (2018), that carbohydrate intake is also positively correlated with HbA1c. Although the relationship between total carbohydrates and HbA1c can be partly explained by energy intake. Little is known about which carbohydrate foods affect HbA1c levels. (Wang et al., 2018) examined that HbA1c levels in a low carbohydrate diet (8.5\%) decreased significantly ( $p<0.05)$ compared to a low-fat diet (4\%).

Based on the results of FFQ's interview, the subject of the most commonly consumed carbohydrate staple food is rice (200 g/meal in 2-3 times per day). According to Haimoto et al. (2018), two staple foods, rice and noodles, were the most common carbohydrate sources and show that the restriction of moderate carbohydrates, especially carbohydrates from rice and noodles, caused a tremendous decrease in HbA1c levels with T2DM.

\section{The relationship between vitamin C intake and HbA1c}

Most subjects had inadequate vitamin C intake. Only 2 subjects with high food intake. In line with the research of Franke et al., (2013) that vitamin C intake from most individuals was lower than 90-100mg per day. The results showed no significant difference between vitamin $\mathrm{C}$ intake and HbA1c. This supports the study conducted by Dakhale et al (2011); Hamed et al.,
(2016) and Prajapat et al (2017).

Donin et al. (2015) revealed the risk of type 2 diabetes was more determined by systemic vitamin $\mathrm{C}$ levels, rather than vitamin $\mathrm{C}$ intake. The effect of vitamin $\mathrm{C}$ intake on systemic vitamin $\mathrm{C}$ status was modified by other factors including absorption and bioavailability. Diabetic subjects require a higher dose of vitamin $\mathrm{C}$ than recommended food intake (RDA) (Malazy et al., 2014).

Moghaddam et al. (2002) states that giving $1 \mathrm{~g}$ of vitamin $\mathrm{C}$ per day for 3 months, the pharmacological effects of vitamin $\mathrm{C}$ on hemoglobin A1c (HbA1c) were also not significant ( $\mathrm{p}>\mathrm{0.05}$ ). This is because a decrease in HbA1c levels occurs due to better weight loss and glucose control, not because of the effects of vitamin C.

\section{The relationship between vitamin E intake and HbA1c}

The results of this study are in accordance with Dass's study, 2018; Vijayakumar et al., 2011 and Manzella et al., 2001 which stated vitamin $\mathrm{E}$ was associated with a decrease in HbA1c levels.

Subjects with a larger dose of vitamin $\mathrm{E}$ and a longer treatment period can experience increased benefits of vitamin $\mathrm{E}$. Smaller doses of vitamin E may not be enough to increase vitamin $\mathrm{E}$ levels (Xu et al., 2014). A study from Rafighi et al. (2013) showed that supplementation of vitamin C and vitamin $\mathrm{E}$ for three months had a significant reduction in HbA1c levels in type 2 diabetes patients compared to the placebo group. This implies that vitamin E supplements for type 2 diabetics can improve tissue sensitivity to insulin and stress due to oxidative free radicals, delaying the occurrence of cardiovascular disorders.

\section{The relationship between age and HbA1c}

Pani et al. (2008) stated that the HbA1c value was positively associated with age in 
the non-diabetic population $(\mathrm{p}<0.001)$. Each 1-year increase was associated with an increase in the $\mathrm{A} 1 \mathrm{C}$ unit with non-diabetic samples. One such explanation was a change in the level of glycation associated with age.

\section{The relationship between gender and HbA1c}

Ramadan and Marissa (2015) showed the results of the study that most DM patients were female with HbA1c values $\geq 6.5$. Female gender was associated with high BMI. This may be due to higher estrogen levels in girls (Akesson et al., 2015). This can be caused by differences in body fat composition and sexual hormone levels between women and men (Ernawati et al., 2004). HbA1c levels in women over 50 years of age are higher than men (Nagakami et al., 2017).

The study of Yuan et al. (2014) showed that female patients significantly had high HbA1c levels. Female patients in the 45-54 year group were also positively associated with changes in HbA1c. Menstrual women was faster erythrocyte replacement (Ma et al., 2016).

\section{The relationship between physical exercise and HbA1c}

In this study, there was no significant relationship between physical exercise and HbA1C levels, in line with the study of Ghorbani et al. (2012) showing DM patients with 4 weeks of physical exercise. This was because the length of physical exercise was too short. Decreasing $\mathrm{HbA1C}$ levels depends on the continuity and length of physical exercise. This study contradicts the study of Ramadhanisa et al (2013) which states that there is a significant relationship between physical activity and HbA1c levels in DM patients. Structured sports training of more than 150 minutes per week was associated with a reduction in $\mathrm{HbA1c}$ greater than 150 minutes or less per week (Umpierre et al.,
2017). The Jagtap et al., (2015) study in Japan stated that regular aerobic exercise such as walking and yoga was associated with a significant reduction in HbA1c in adults with T2DM.

Based on the results of this study, it can be concluded that there was no relationship between carbohydrate intake and HbA1c levels, but there was a relationship between vitamin $\mathrm{E}$ and $\mathrm{HbA1c}$ levels.

\section{AUTHOR CONTRIBUTIONS}

Dwi Astuti Dian Andarwati collected data amd wrote the manuscript. Bhisma Murti examined data analysis and interpreted data analysis. Endang Sutisna Sulaeman suggested discussion about the effects of vitamin $\mathrm{C}$, vitamin $\mathrm{E}$, and carbohydrate on HbA1c level.

\section{CONFLICT OF INTEREST}

There was no conflict of interest in this study.

FUNDING AND SPONSORSHIP

This study used personal fund.

\section{ACKNOWLEDGEMENT}

We would like to thank to Prodia Surakarta Clinic, Surakarta, Central Java, Indonesia for giving permission to take the data.

\section{REFERENCE}

Akesson K, Hanberger L and Samuelsson U (2015). The influence of age, gender, insulin dose, BMI, and blood pressure on metabolic control in young patients with type 1 diabetes, Pediatric Diabetes.8 (16):581-586.

Bailo BG, El-Sohemy A, Haddad PS, Arora $\mathrm{P}$, Zaied FB, Karmali M, Badawi A (2011). Vitamins D, C, and $E$ in the prevention of type 2 diabetes mellitus: modulation of inflammation and 
oxidative stress, Dove press journal. 5: 7-19. doi: 10.2147/BTT.S14417.

Boeing H, Weisgerber UM, Jeckel A, Rose HJ, Kroke A (2000). Association between glycated hemoglobin and diet and other lifestyle factors in a nondiabetic population: cross-sectional evaluation of data from the Potsdam cohort of the European Prospective Investigation into Cancer and Nutrition Study, Am J Clin Nutr. 71: 111522.

Bushman AB (2015). Slippery slope of prediabetes using physical activity and nutrition to promote health. ACSM's Health \& Fitness Journal. 19(3): 5-9.

Dass AS (2018). Effect of Vitamin E and omega 3 fatty acids in type 2 diabetes mellitus patients, J Adv Pharm Technol Res. 32-36. doi: 10.4103/japtr.JAPTR.

Ebe K, Bando H, Yamamoto K, Bando M, Yonei Y (2017). Daily carbohydrate intake correlates with $\mathrm{HbA1c}$ in low carbohydrate diet (LCD). Journal Diabetology. 1(1): 6-11.

Ernawati F, Muhardiyatiningsih, Effendi R, Herman S (2004). Profil distribusi lemak tubuh dan lemak darah dewasa di pedesaan dan perkotaan. Penelitian Gizi Makan (PGM). 27(1): 1-9.

Feinman RD, Pogozelski WK, Arne A, Bernstein RK, Fine EJ, Westman EC, Anthony A, Lynda F, et al. (2014) Dietary carbohydrate restriction as the first approach in diabetes management: Critical review and evidence base. Nutrition. 31(1): 1-13. doi: 10.1016/j.nut.2014.06.011.

Franke SIR, Müller LL, Santos MC, Fishborn A, Hermes L, Molz P, Pereira CS, Wichmann FMA, Harta JA, Maluf SW, Prá D (2013). Vitamin C Intake Reduces the Cytotoxicity Associated with Hyperglycemia in Prediabetes and Type 2 Diabetes. Bio Med Research International. 1-6.

Ghorbani A, Ziaee A, Yazdi Z, Khoeyni MH, Khoshpanjeh M (2012). Effects of short-term exercise program on blood glucose, lipids, and HbA1c in Type 2 diabetes, Iranian Journal and Obesity. 4(1):19-25.

Haimoto $\mathrm{H}$, Watanabe $\mathrm{S}$, Komeda $\mathrm{M}$, Wakai K (2018). The impact of carbohydrate intake and its sources on hemoglobin A1c levels in Japanese patients with type 2 diabetes not taking anti-diabetic medication. Diabetes, Metabolic Syndrome and Obesity: Targets and Therapy.11: 53-64.

Hamed AT, Al Zinati SM, Al Swirky A (2016). The Effect of Vitamin C Alone or in Combination with Vitamin E on Fasting Blood Glucose, Glycosylated Hemoglobin and Lipid Profile in Type 2 Diabetic Patients (Gaza Strip). Jordan Journal of Pharmaceutical Sciences. 9(1):1-12.

Hinzmann R, Schlaeger C, Tran C T (2012). What do we need beyond hemoglobin A1c to get the complete picture of glycemia in people with diabetes?. International Journal of Medical Sciences. 9(8):665-681 doi: 10.7150/ijms.4520.

Idris H, Hasyim H, Utama F (2013). Analysis of diabetes mellitus determinants in Indonesia: A Study from the Indonesian Basic Health Research. 49(4): 291-298.

Jagtap MW, Rohankar PH and Kale SA (2015). Exercise reduces HBA1C and mostly brings good control in type 2 diabetes mellitus. International Journal of Science and Research. 4(10): 2014-2016.

Ma Q. Liu H, Xiang G, Shan W, Xing W (2016). Association between glycated hemoglobin A1c levels with age and 
gender in Chinese adults with no prior diagnosis of diabetes mellitus, Biomedical Reports. 4: 737-740. doi: 10.3892/br.2016.643.

Malazy T, Nikfarc OS, Larijanib B, Abdollahi M (2014). Influence of ascorbic acid supplementation on type 2 diabetes mellitus in observational and randomized controlled trials; A Systematic Review with Meta-Analysis. J Pharm Pharm Sci. 17(4): 554 - 582.

Manzella D, Barbieri M, Ragno E, Paolisso G (2001). Chronic administration of pharmacologic doses of vitamin $\mathrm{E}$ improves the cardiac autonomic nervous system in patients, Am J Clin Nutr.73:1052-1057.

Montonen J, Paul K, Ritva AJ, Antti R (2004). Dietary Antioxidant Intake and Risk of Type 2 Diabetes, Diabetes Care. 27(2):362-366.

Nakagami T, Junko O, Tadasu K, Yasuko U (2017). SciTeMed Publishing Group Diabetes and Endocrinology Effect of Hemoglobin Levels and Sex on HbA1c Levels among Japanese. Diabetes and Endocrinology. 1(1): 2-6. doi: 10.24983/scitemed.de.2017.00044.

Nanditha A, Ma RCW, Ambady R, Chamukuttan S, Juliana CCN, Seng CK, Jonathan SE, Paul ZZ (2016). Diabetes in Asia and the Pacific: Implications for the Global Epidemic. Diabetes Care. 39(March):472-485. doi: 10.2337/dc15-1536.

Pani LN, Korenda L, Meighs JB, Driver C, Chamany S, Fox CS, Sullivan L, D'Agostino B, Nathan DM, Gostino R (2008) Effect of Aging on A1C Levels in Individual Without Diabetes. Diabetes Care. 31(10):1991-1996. doi: 10.2337/dco8-0577.J.B.M.

Paputungan SR, Sanusi H (2014). Peranan Pemeriksaan Hemoglobin A 1c pada Pengelolaan Diabetes Melitus. Cermin
Dunia Kedokteran-220. 41(9):650655.

Prajapat R, Bhattacharya I, Jakhalia A (2017). Combined effect of vitamin C and $\mathrm{E}$ dose on type 2 diabetes patients. Advances in Diabetes and Metabolism Journal. 5(2): 21-25. doi: 10.13189/adm.2017.050201.

Rahmawati, Tahlil T, Syahrul (2016). Effects of diabetes self-management education program on self-management in patients with diabetes mellitus type 2. Jurnal Ilmu Keperawatan. 4: 46-58.

Ramadhanisa A, Larasati TA, Mayasari Diana (2013). Hubungan aktivitas fisik dengan kadar Hba1c pasien diabetes melitus tipe 2 di laboratorium patologi klinik RSUD DR. H. Abdul Moeloek Bandar Lampung. Medical Journal of Lampung University. 2(4): 44-51.

Selvin E, Zhu H, Frederick L, Brancati (2009). Elevated $\mathrm{A} 1 \mathrm{C}$ in adults without a history of diabetes in the US. Diabetes Care. 32(5):828-33. doi: 10.2337/dco8-1699.

Setiawan B, Suhartono E (2005). Stres Oksidatif dan Peran Antioksidan pada Diabetes Melitus. Majalah Kedokteran Indonesia. 5(2).

Soewondo P, Pramono LA (2011). Prevalence, characteristics, and predictors of pre-diabetes in Indonesia. Med $\mathbf{J}$ Indones. 20(4): 283-294.

Tay J, Marsh NDL, Thompson CH, Noakes M, Buckley JD, Wittert GA, Yancy WS, Brinkworth GD (2015). Comparison of low- and high-carbohydrate diets for type 2 diabetes management: a randomized trial. Am J Clinical Nutrition. 102(4): 780-790. doi: 10.3945/ajen.115.112581.1.

Umpierre D, Ribeiro PAB,. Kramer CK, Leita o CB, Zucatti ATN, Azevedo 
MJ, Gross JL, Ribeiro JP, Schaan BD (2017). Clinician 'S Corner Physical Activity Advice Only or Structured With HbA 1c Levels in Type 2 Diabetes. JAMA. 305(17): 1790-1799.

Vijayakumar APR, Jayesh KB, Varghese JM, Das S (2011). Supplementation of vitamin E Improves cognitive status and oxidative stress in type 2 Diabetes Mellitus. IRJP. 2(11): 169-172.

Wang LL, Wang Q, Hong Y, Ojo O, Jiang Q, Hou YY, Huang YH, Wang XH (2018). The Effect of Low-Carbohydrate Diet on Glycemic Control in Patients with Type 2 Diabetes Mellitus. Nutrients. 10,661: 1-13 doi: 10.3390/nu10060661.

Weykamp C (2013). HbA1c: A review of analytical and clinical aspects. Annals of Laboratory Medicine. 33(6): 393400.

Wilson R, Willis J, Gearry R, Skidmore P, Fleming E, Frampton C, Carr A (2017). Inadequate vitamin $C$ status in prediabetes and type 2 diabetes mellitus: Association with glycaemic control, obesity and smoking. Nutrients. 9:1-15. doi: 10.3390/nu9090997.

Xu R, Zhang S, Tao A, Chen G, Muxun Zhang (2014). Influence of vitamin E supplementation on glycaemic control: A Meta-Analysis of Randomised Controlled Trials. Plos One. 9(4). doi: 10.1371/journal.pone.0095008.

Yanai H, Adachia H, Masuia Y, Katsuyamaa H, Kawaguchia A, Hakoshimaa M, Waragaia Y, Harigaea T, Hamasakia H, Sako A (2018). Exercise Therapy for Patients With Type 2 Diabetes: A Narrative Review. J Clin Med Res. 10(5): 365-369.

Yuan S, Huang CN, Liao HC, Lin YT, Wang YH (2014). Glycemic control outcomes by gender in the pay-for-performance system: A Retrospective Database Analysis in Patients with Type 2 Diabetes Mellitus. International journal of endocrinology. 1-11. 